\title{
Karakteristik Fisikokimia dan Sensoris Es Krim Ubi Jalar Ungu (Ipomoea Batatas L.) Dengan Subtitusi Pemanis Ekstrak Daun Stevia (Stevia Rebaudiana Bertoni M.) dan Berbagai Jenis Stabilizer
}

\section{Physicochemical and Sensory Characteristics of Purple Sweet Potato (Ipomoea Batatas L.) Ice Cream with Sweetener Substitution of Stevia Leaf Extract (Stevia Rebaudiana Bertoni M.) and Various Types of Stabilizers}

\author{
Bambang Nugroho', Arif Prashadi Santosa ${ }^{2}$, Solihin Amirudin ${ }^{3}$ \\ ${ }^{1,2,3}$ Program Studi Agroteknologi Fakultas Pertanian dan Perikanan \\ Universitas Muhammadiyah Purwokerto
}

\begin{tabular}{l} 
ARTICLE INFO \\
\hline Article history: \\
DOI: \\
10.30595/pspfs.v2i.193 \\
Submitted: \\
July 29, 2021 \\
Accepted: \\
Sept 10, 2021 \\
Published: \\
Nov 10, 2021 \\
\hline Keywords: \\
Ice Cream, Purple Potato, \\
Stevia, Physicochemical \\
Characteristics, Sensories \\
Characteristics
\end{tabular}

\begin{abstract}
This study aims to determine the effect of sweetener concentration, various types of stabilizers and their interactions on proximate, antioxidant and sensory content of ice cream. The study was conducted using a Factorial Completely Randomized Design (CRD) consisting of two factors. The first factor is the comparison of sweetener concentration with 3 levels of $100 \%$ sugar sweetener (D1), 50\% sugar sweetener: $50 \%$ stevia extract sweetener (D2) and $100 \%$ stevia extract sweetener (D3) while the second factor is the type of stabilizer with 3 levels namely, agar. - agar (S1), Gelatin (S2) and CMC (S3). The results obtained were analyzed using the F test and followed by the DMRT test with a confidence level of $95 \%$. The results showed that the comparison of sweetener concentration (D) and treatment interaction (DxS) had a significant effect. While the sensory analysis has a significant effect on the texture, taste, overall variables and does not significantly affect the aroma variable. The best treatment in the proximate analysis of sensory analysis is the treatment of using 50\% sugar and 50\% stevia and agar-agar (D2S1) stabilizer with the organoleptic score of fragrance, texture, taste and preference respectively were 3.80 (normal); 3.60 (slightly soft); 3.80 (good); 4.10 (liked), and the Physicochemical value of overrun, melting time, fibre content, viscosity, antioxidant, and sugar content respectively were $42,5 \% ; 14,06$ minutes; $0,3107 \% ; 1,217 \mathrm{cP}$; $11,65 \% ; 20,33 \%$.
\end{abstract}

This work is licensed under a Creative Commons Attribution 4.0 International License.

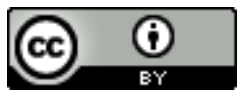

Corresponding Author:

Bambang Nugroho

Program Studi Agroteknologi Fakultas Pertanian dan Perikanan

Universitas Muhammadiyah Purwokerto

Email: agroteknologi@ump.ac.id

\section{PENDAHULUAN}

Es krim merupakan produk olahan susu yang dibuat melalui proses pembekuan dan agitasi (pengadukan) dengan prinsip membentuk rongga udara pada campuran bahan es krim (Ice Cream Mix/ICM) sehingga dihasilkan pengembangan volume es krim. ICM pada es krim dapat dibuat dari campuran susu, produk susu, 
bahan pemanis, bahan penstabil, bahan pengemulsi, serta penambah cita rasa (Susilorini dan Sawitri (2006), Harris (2011).

Dengan tingkat konsumsi per kapita 0,63 liter per tahun, potensi pasar es krim Indonesia masih terbuka sangat lebar (Pratama dan Simamora, 2018_). Untuk menambah kandungan antioksidan dan serat pangan pada eskrim dapat disubtitusikan ubi jalar ungu ke dalam bahan bakunya (Suda et al., 2003), (Meyer, 1982). Ubi jalar ungu potensial dimanfaatkan sebagai bahan pangan fungsional karenamemiliki antosianin, pigmen yang menyebabkan daging umbi berwarna ungu,yang mempunyai aktivitas antioksidan. Keberadaan senyawa fenol selainantosianin juga penting karena bersinergi dengan antosianin dalam menentukanaktivitas antioksidan ubijalar. Hasil pengujian ekstrak delapan klon ubijalar unguyang bervariasi intensitasnya, menunjukkan bahwa antosianin dan senyawa fenolberkorelasi positif dengan aktivitas antioksidan. Kandungan serat pangan yangbermanfaat untuk pencernaan dan indeks glikemiknya yang rendah sampaimedium, juga merupakan nilai tambah ubijalar sebagai pangan fungsional (Ginting et al., 2011).

Dalam pembuatan es krim ada beberapa bahan yang digunakan salah satunya gula pasir. Namun, Mengonsumsi gula dalam jumlah besar dapat mengakibatkan tingginya kadar gula dalam darah sehingga mengakibatkan diabetes serta menyebabkan obesitas. Karenanya perlu ada bahan pemanis alami yang memiliki kalori yang lebih rendah, salah satunya ekstrak stevia (Raini dan Isnawati, 2011).

Pemanis ekstrak daun stevia sangat baik digunakan oleh masyarakat, terutama sebagai pengganti gula pasir bagi para penderita penyakit diabetes mellitus karena kalorinya yang rendah, dengan dosis maksimum 3 $\mathrm{mg} / \mathrm{kgbb} / \mathrm{hr}$. Daun stevia mengandung glycoside yang mempunyai rasa manis tapi tidak menghasilkan kalori. Stevioside dan rebaudioside merupakan konstituen utama dari glycoside dengan gabungan dari molekul gula yang berbeda seperti yang terdapat pada tanaman stevia (Raini dan Isnawati, 2011). Stevia memiliki nilai kalori yang lebih rendah yaitu sebesar 2,7 Kal/gram Savita et al. (2004), jika dibandingkan gula pasirdengan kalori $1.819,86 \mathrm{kal} / \mathrm{g}$ (Widodo et al., 2015). Selain itu tingkat kemanisan stevia 200-300 kali lebih manis dari sukrosa (Buchori, 2007).

Selain gula dalam pembuatan es krim juga diperlukan bahan yang berfungsi sebagai penstabil yaitu stabilizer. Bahan penstabil dapat meningkatkan viskositas, konsistensi fisik dan stabilitas (Buckle et al, 1987). penelitian Istiqomah dkk (2017) menyatakan, Stabilizer juga berfungsi meningkatkan nilai overrun pada es krim, dimana pada es krim edamame nilai rata-rata overrun berkisar antara $(15,56 \%-38,95 \%$.).

Berdasarkan hal diatas perlu adanya penelitian terhadap es krim yang memiliki kandungan rendah kalori dan tekstur yang disukai masyarakat berdasarkan karakteristik proksimat, antioksidan dan sensorisnya.

\section{METODE PENELITIAN}

\section{Alat dan Bahan}

Alat: Alat - alat yang digunakan untuk membuat es krim yaitu mixer, blender, Baskom,gelas ukur, sendok pengaduk, termometer, kompor, kulkas, Freezer, kertas saring, timbangan analitik digital, desikator, stopwatch, cawan, oven, tanur listrik, cawan porselen, erlenmeyer, pipet, beaker glass, blender, corong, kertas saring, Soxhlet, mikropipet, panelis, borang, kertas label, termos es, saringan, kamera, alat tulis, panci pengukus, spektrofotometer, viscometer broookfiled.

Bahan: Bahan-bahan yang digunakan untuk membuat es krim diantaranya Daun stevia kering dari Karanganyar-Jawa Tengah, air, Bubuk full cream, bubuk whipped cream, susu bubuk skim, ubi jalar ungu, agaragar, garam, cmc, gelatin,kuning telur, cup es krim ukuran 50, aquadest, larutan petrolium benzen, $\mathrm{H}_{2} \mathrm{SO}_{4} 0,3 \mathrm{~N}$, $\mathrm{NaOH} 1,5 \mathrm{~N}$, Aceton/N-hexane, larutan Luff-Schoorl, $\mathrm{H}_{2} \mathrm{O}_{4}, \mathrm{KI} 20 \%, \mathrm{Na}_{2} \mathrm{SO}_{3}$, larutan DPPH, metanol, air putih.

\section{Rancangan Percobaan}

Rancangan percobaan digunakan Rancangan Acak Lengkap (RAL) dengan pola faktorial dimana terdapat 2 faktor dan diulang 3 kali. Faktor pertama adalah tiga macam pemanis yaitu : D1: $100 \%$ gula pasir, D2: $50 \%$ gula pasir dan 50\% ekstrak stevia, D3: $100 \%$ ekstrak stevia, Faktor kedua adalah tiga jenis stabilizer, yaitu : S1: Agar-agar, S2: Gelatin, S3: CMC, kemudian dilakukan analisis proksimat dan sensoris. Data yang diperoleh dianalisis dengan menggunakan analisis sidik ragam dan jika terdapat perbedaan yang nyata antar perlakuan dilanjutkan dengan uji DMRT taraf $5 \%$.

\section{Pelaksanaan Penelitian}

1. Pembuatan Larutan Ekstrak Daun Stevia (Halim, 2019 dengan modifiksi): bubuk daun stevia lalu ditimbang sebanyak 5,03 gram, bubuk stevia dimasukan kedalam gelas, air direbus hingga mendidih, lalu diamkan sampai suhu kurang lebih $80^{\circ} \mathrm{C}$, air sebanyak $100 \mathrm{ml}$ dituangkan kedalam gelas yang berisi stevia, lalu diaduk selama 5 detik dan diamkan selama 2 menit kemudian disaring menggunakan kertas saring.

2. Pembuatan Larutan Gula Pasir: Gula pasir ditimbang sebanyak 151 gram lalu dimasukan kedalam gelas, Air direbus hingga mendidih, lalu diamkan sampai suhu kurang lebih $80^{\circ} \mathrm{C}$, Air sebanyak $100 \mathrm{ml}$ dituangkan kedalam gelas yang berisi gula pasir, aduk sampai gula larut. 
3. Pembuatan Es Krim: Ubi jalar ungu dikukus sekitar 15 menit atau sampai matang, Ubi jalar ungu dikupas dan ditimbang sebanyak 100 grm, Ubi jalar ungu dihaluskan menggunakan blender, lalu disaring, Ubi jalar, bubuk full cream, bubuk wipped cream, susu bubuk skim, larutan gula atau stevia, stabilizer (agar - agar, CMC, atau Gelatin), dan garam dimasukan kedalam baskom, Air sebanyak $465 \mathrm{ml}$ dimasukan kedalam baskom, Bahan - bahan tersebut dicampurkan menggunakan mixer dengan kecepatan tinggi selama kurang lebih 10 menit, Adonan es krim dimasukan kedalam panci lalu dengan api kecil, Adonan diaduk dan diukur suhunya sampai $80^{\circ} \mathrm{C}$, Adonan dipindahkan kembali kedalam baskom lalu ditunggu sampai dingin, Adonan dimixer selama 5 menit lalu bahan pengemulsi dimasukan, Adonan kembali dimixer dengan kecepatan tinggi selama 10 menit, Adonan lalu diukur volumenya, Adonan dimasukan kedalam pendingin dan diamkan selama 24 jam, Adonan yang telah didiamkan dimixer kembali dengan kecepatan tinggi selama kurang lebih 10 menit, Adonan diukur kembali volumenya, Adonan dimasukan kedalam cup es krim dan simpan didalam freezer sampai membeku.

4. Analisis Sensoris

Menurut (SNI 01-2346-2006), analisis sensori atau organoleptik merupakan cara pengujian menggunakan indera manusia sebagai alat utama untuk menilai mutu produk. Metode yang digunakan menggunakan uji organoleptik 5 taraf yang meliputi kesukaan secara keseluruhan, aroma, dan rasa. Pengamatan sample uji dilakukan oleh 15 - 25 panelis tidak terlatih. Data yang diperoleh dari hasil uji kesukaan kemudian dapat dicari nilai rata-rata yang digunakan untuk analisis Varian. Apabila terdapat perbedaan yang nyata pada sampel, maka dilakukan uji lanjut dengan metode DMRT

5. Analisis Proksimat

a. Kadar Serat Kasar: Kadar serat kasar ditentukan menggunakan metode (AOAC, 2006).

b. Kadar Gula Total: Kadar gula total adalah kandungan gula keseluruhan dalam suatu bahan pangan baik monosakarida, disakarida, polisakarida, maupun oligosakarida. Kadar gula total ditentukan dengan menggunakan metode Luff Schroll (Sudarmadji et,al. 1989).

c. Analisis Overun: Overrun dalam pembuatan es krim adalah persentase pengembangan volume yaitu kenaikan volume es krim. Overrun dinyatakan dalam persentase (Hadiwiyoto, 1983). Es krim yang baik adalah yang memilki nilai overrun $80 \%$.

d. Pengujian Viskositas (menggunakan viskosimeter) (Jacobs, 1958)

e. Kadar Antioksidan (Shekhar and Anju, 2014)

f. Uji Leleh Es Krim: kecepatan pelelehan dihitung dengan cara es krim ditimbang sebanyak 5 gram kemudian diisikan ke dalam cup dan dibekukan dalam freezer selama 24 jam, sampel dari freezer kemudian diambil dan diletakkan pada suhu kamar dan dibiarkan sampai semua sampel meleleh,waktu yang dibutuhkan sampai semua sampel meleleh dicatat dan selanjutnya dianalisis secara statistik (Nugroho dan Kusnadi, 2015).

\section{HASIL DAN PEMBAHASAN}

\section{Analisi Uji Sensoris}

Berdasarkan hasil dari analisis sensoris yang dilakukan diperoleh data yang kemudian diuji dengan uji $\mathrm{F}$ 5\% dan dilanjut dengan DMRT, sehingga diperoleh rata-rata dan notasi pada Tabel 1.

Tabel 1. Rata-rata dan Notasi Hasil Analisis Sensoris Es Krim Ubi Jalar Ungu dengan Penambahan Pemanis Ekstrak Daun Stevia (Stevia rebaudiana Bertoni M.) dan berbagai jenis Stabilizer

\begin{tabular}{lcccc}
\hline \multicolumn{1}{c}{ Perlakuan } & \multicolumn{5}{c}{ Variabel Pengamatan } \\
\hline Ekstrak Daun Stevia & Aroma & Tekstur & Rasa & Kesukaan \\
\hline D1 & $3.43 \mathrm{~b}$ & $3.47 \mathrm{~b}$ & $3.67 \mathrm{~b}$ & $3.67 \mathrm{~b}$ \\
D2 & $3.56 \mathrm{~b}$ & $3.31 \mathrm{~b}$ & $3.53 \mathrm{~b}$ & $3.76 \mathrm{~b}$ \\
D3 & $2.76 \mathrm{a}$ & $2.76 \mathrm{a}$ & $2.30 \mathrm{a}$ & $2.38 \mathrm{a}$ \\
\hline DMRT 5\% & $*$ & $*$ & $*$ & $*$ \\
\hline Jenis Stabilizer & & & 3.22 & 3.38 \\
S1 & 3.40 & 3.36 & 3.03 & 3.08 \\
S2 & 2.90 & 2.95 & 3.25 & tn \\
S3 & 3.53 & 3.17 & tn & $3.70 \mathrm{~d}$ \\
DMRT 5\% & tn & tn & $3.30 \mathrm{c}$ \\
\hline Interaksi Perlakuan & 3.50 & $3.40 \mathrm{~b}$ & $3.50 \mathrm{c}$ & $4.00 \mathrm{e}$ \\
D1S1 & 3.00 & $3.20 \mathrm{~b}$ & $3.40 \mathrm{~b}$ & $4.10 \mathrm{e}$ \\
D1S2 & 3.65 & $3.70 \mathrm{~b}$ & $3.80 \mathrm{c}$ & $3.80 \mathrm{~b}$ \\
D2S1 & 3.80 & $3.60 \mathrm{~b}$ & & \\
\end{tabular}




\begin{tabular}{lcccc}
\hline D2S2 & 3.30 & $2.80 \mathrm{a}$ & $3.40 \mathrm{~b}$ & $3.40 \mathrm{c}$ \\
D2S3 & 3.90 & $3.55 \mathrm{~b}$ & $3.70 \mathrm{c}$ & $3.80 \mathrm{~d}$ \\
D3S1 & 2.90 & $3.00 \mathrm{a}$ & $2.35 \mathrm{a}$ & $2.45 \mathrm{~b}$ \\
D3S2 & 2.40 & $2.85 \mathrm{a}$ & $2.30 \mathrm{a}$ & $2.55 \mathrm{~b}$ \\
D3S3 & 3.05 & $2.25 \mathrm{a}$ & $2.25 \mathrm{a}$ & $2.15 \mathrm{a}$ \\
\hline DMRT 5\% & th & $*$ & $*$ & $*$ \\
\hline Keterangan: & &
\end{tabular}

\section{Keterangan:}

Angka rata-rata yang diikuti oleh huruf yang sama pada satu kolom yang sama menunjukkan tidak berpengaruh nyata pada DMRT 5\%.

tn : Tidak Berpengaruh Nyata

* Berpengaruh nyata

\section{Aroma}

Berdasarkan dari hasil uji lanjut subtitusi pemanis (D) berpengaruh nyata pada variabel pengamatan aroma. Sedangkan perlakuan berbagai jenis stabilizer (S) dan interaksi perlakuan subtitusi pemanis dan jenis stabilizer (DxS) tidak berpengaruh nyata (Tabel 1.).

Aroma eskrim yang paling disukai yaitu perlakuan $50 \%$ gula 50\% stevia (D2) karena bau stevia tidak terlalu menyengat dan memberikan aroma yang khas padaes krim. Sedangkan perlakuan yang paling tidak disukai adalah $100 \%$ stevia (D3) karena bau stevia terlalu kuat sehingga membuat painelis kurang menikmati es krim. Aroma pada eskrim dipengaruhi oleh bahan bahan yang digunakan dalam pembuatan es krim. Selain itu pada es krim tanpa stevia agak sulit menentukan baunya sehingga nilainya mendekati netral. Hal ini sesuai dengan pendapat Nugroho dan Kusnadi (2015), aroma yang dihasilkan produk pangan adalah senyawa-senyawa yang muda menguap dan menghasilkan bau. Produk es krim senyawa volatil yang sukar menguap, karena es krim disajikan dalam kondisi dingin, sehingga sangat sulit membedakan aroma pada es krim. Seperti yang bisa kita lihat stabilizer tidak memberikan pengaruh nyata terhadap penilaian rasa. Hal ini sesuai dengan pendapat Prasetyo (2013) penstabil tidak mempengaruhi rasa es krim karena merupakan zat yang tidak berasa dan berbau.

\section{Tekstur}

Berdasarkan dari hasil uji lanjut subtitusi pemanis (D) serta interaksi perlakuan subtitusi pemanis dan jenis stabilizer (DxS) berpengaruh nyata pada variabel pengamatan tekstur. Sedangkan Perlakuan berbagai jenis stabilizer (S) tidak berpengaruh nyata. Pada uji sensoris tekstur dipengaruhi oleh konsentrasi gula yang diberikan seperti terlihat pada Tabel 1.

Perlakuan yang paling disukai adalah $100 \%$ gula pasir (D1) dengan nilai 3,47 (Suka) dan yang paling tidak disukai adalah $100 \%$ stevia (D3) dengan nilai 2,76 (tidak suka). Hal ini menunjukan bahwa penambahan gula pasir mempengaruhi tekstur dari eskrim. Dimana semakin banyak gula maka teksturnya semakin disukai. Gula menghalangi pembentukan kristal es selama pembekuan produk. Fenomena ini terjadi karena molekul gula menarik molekul air sehingga menggangu pembentukan kristal es. Dengan demikian gula membantu mencegah pembentukan kristal es yang besar, akibatnya tekstur yang dihasilkan lebih lembut (Muse dan Kartel, 2004).

Dari Tabel 1. diketahui bahwa nilai tertinggi terdapat pada perlakuan 100\% gula pasir dan CMC (D1S3) dan yang terendan pada 100\% stevia dan CMC (D3S3). Dari data tersebut disimpulkan bahwa panelis lebih menyukai es krim yang lembut dengan tekstur sedikit kenyal, dan relatif mudah meleleh didalam mulut. Menurut Arbuckle (1986), tekstur es krim yang lembut sangat dipengaruhi oleh komposisi campuran, pengolahan dan penyimpanan. Salah satu bahan yang mempengaruhinya yaitu gula. Gula tidak hanya berfungsi sebagai pemberi rasa manis pada es krim, tapi juga menurunkan titik beku adonan, sehingga adonan tidak terlalu cepat membeku saat diproses. Agar udara yang masuk kedalam adonan bisa lebih banyak sehingga tekstur menjadi lebih lembut. Karenanya pada perlakuan D3S3 yang tanpa menggunakan gula pasir teksturnya menjadi lebih kasar karena banyak air yang mengkristal.

\section{Rasa}

Berdasarkan dari hasil uji lanjut subtitusi pemanis (D) berpengaruh nyata pada variabel pengamatan rasa serta interaksi perlakuan subtitusi pemanis dan jenis stabilizer (DxS). Sedangkan perlakuan berbagai jenis stabilizer (S) tidak berpengaruh nyata. Pada uji sensoris rasa dipengaruhi oleh konsentrasi gula yang diberikan seperti terlihat pada Tabel 1 .

Es Krim yang paling disukai adalah es krim dengan perlakuan $100 \%$ gula pasir (D1) karena gula memberikan rasa yang enak pada es krim dan lebih familiar jika dibandingkan dengan stevia. Sedangkan yang paling tidak disukai adalah perlakuan $100 \%$ stevia (D3) karena ekstrak stevia yang terlalu pekat mengakibatkan rasanya agak sedikit pahit dan kurang disukai panellis. Seperti yang bisa kita lihat stabilizer tidak memberikan pengaruh nyata terhadap penilaian rasa. Hal ini sesuai dengan pendapat Prasetyo (2013) penstabil tidak mempengaruhi rasa es krim karena merupakan zat yang tidak berasa dan berbau.

Terdapat beberapa faktor yang mempengaruhi penerimaan panelis terhadap rasa, antara lain senyawa kimia, suhu, konsentrasi, dan interaksi dengan komponen rasa yang lain. Produk yang memiliki rasa tidak enak 
maka tidak akan diterima oleh konsumen walaupun warna, aroma, dan teksturnya baik. Oleh sebab itu, rasa merupakan salah satu faktor yang penting dalam keputusan konsumen untuk menerima atau menolak suatu produk (Winarno, 1997).

\section{Kesukaan}

Berdasarkan dari hasil uji lanjut pemanis (D) dan interaksi perlakuan subtitusi pemanis dan jenis stabilizer (DxS) berpengaruh nyata pada variabel pengamatan kesukaan. Sedangkan perlakuan berbagai jenis stabilizer (S) tidak berpengaruh nyata. Pada uji sensoris kesukaan berpengaruh nyata pada interaksi perlakuan seperti terlihat pada Tabel 1 .

Perlakuan yang terbaik adalah 50\% gula pasir dan 50\% stevia dan stabilizer agar (D12S1) karena tekstur, rasa dan aroma es krim yang terdapat pada perlakuan tersebut dirasa paling sesuai. Sedangkan perlakuan yang terendah adalah $100 \%$ stevia dan CMC (D3S3) hal ini dikarenakan penggunaan ekstrak daun stevia yang banyak sehingga terasa pahit, dan tekstur dari es krim itu sendiri. Ekstrak daun stevia memiliki rasa manis yang berkalikali lipat dari rasa manis gula, karenanya saat menggunakannya terlalu banyak maka akan mengakibatkan rasa menjadi pahit.Rasa pahit inilah yang merusak rasa dari es krim. Hal ini sesuai dengan pendapat Rachmawanti W (2012) yang menyatakan bahwa kesukaan keseluruhan es krim ditentukan oleh tekstur, warna, dan rasa es krim yang dihasilkan, karena konsumen menyukai warna yang menarik, tekstur halus dan kokoh, serta rasa yang lezat.

\section{Analisis Proksimat}

\section{Overrun}

Berdasarkan dari hasil uji lanjut subtitusi pemanis (D) serta interaksi perlakuan subtitusi pemanis dan jenis stabilizer $(\mathrm{DxS})$ berpengaruh nyata pada variabel pengamatan overrun. Sedangkan perlakuan berbagai jenis stabilizer (S) tidak berpengaruh nyata. Pengaruh konsentrasi gula pada uji overrun dapat dilihat pada Tabel 2.

Tabel 2. Rata-rata dan Notasi Hasil Analisis Proksimat dan Sensoris pada Es Krim Ubi Jalar Ungu Substitusi Pemanis Ekstrak Daun Stevia (Stevia rebaudiana Bertoni M.) dan Berbagai Jenis Stabilizer

\begin{tabular}{|c|c|c|c|c|c|c|}
\hline \multirow{2}{*}{$\frac{\text { Perlakuan }}{\text { Pemanis Daun Stevia }}$} & \multicolumn{6}{|c|}{ Variabel Pengamatan } \\
\hline & Overrun (\%) & $\begin{array}{l}\text { U. Leleh } \\
\text { (menit) }\end{array}$ & K. Serat (\%) & Viskositas (cP) & $\begin{array}{c}\text { K. AO } \\
(\%)\end{array}$ & K. Gula (\%) \\
\hline D1 & $44,97 \mathrm{c}$ & $16.083 \mathrm{a}$ & 0.3103 & $1300 \mathrm{c}$ & 11,62 & $35,003 \mathrm{c}$ \\
\hline D2 & $40.87 \mathrm{~b}$ & $17.13 \mathrm{~b}$ & 0.31 & $1167 \mathrm{~b}$ & 11,63 & $20,54 \mathrm{~b}$ \\
\hline D3 & $35.1 \mathrm{a}$ & $23.253 \mathrm{c}$ & 0.3091 & $1033 \mathrm{a}$ & 11,63 & $8,32 \mathrm{a}$ \\
\hline DMRT 5\% & $*$ & $*$ & tn & $*$ & $\operatorname{tn}$ & $*$ \\
\hline \multicolumn{7}{|l|}{ Jenis stabilizer } \\
\hline $\mathrm{S} 1$ & 35.6 & 16.813 & 0.3101 & 1206 & 11,613 & 21,14 \\
\hline $\mathrm{S} 2$ & 41.63 & 18.96 & 0.31 & 1167 & 11,65 & 21,123 \\
\hline $\mathrm{S} 3$ & 43.03 & 20.697 & 0.3093 & 1128 & 11,623 & 21,66 \\
\hline DMRT $5 \%$ & tn & tn & tn & tn & tn & tn \\
\hline \multicolumn{7}{|l|}{ Interaksi Perlakuan } \\
\hline D1S1 & $35.7 \mathrm{ab}$ & $14.06 \mathrm{a}$ & 0.3103 & $1400 \mathrm{~d}$ & 11,58 & $34,78 \mathrm{c}$ \\
\hline D1S2 & $32.2 \mathrm{a}$ & $16.12 \mathrm{~b}$ & 0.3103 & $1250 \mathrm{~cd}$ & 11,65 & $35,21 \mathrm{c}$ \\
\hline D1S3 & $37.4 \mathrm{~b}$ & $18.07 \mathrm{~d}$ & 0.3103 & $1250 \mathrm{~cd}$ & 11,63 & $35,02 \mathrm{c}$ \\
\hline D2S1 & $42.5 \mathrm{c}$ & $14.06 \mathrm{a}$ & 0.3107 & $1217 \mathrm{bc}$ & 11,65 & $20,33 \mathrm{~b}$ \\
\hline $\mathrm{D} 2 \mathrm{~S} 2$ & $44.8 \mathrm{~cd}$ & $17.34 \mathrm{c}$ & 0.31 & $1200 \mathrm{bc}$ & 11,63 & $19,87 \mathrm{~b}$ \\
\hline D2S3 & $43.3 \mathrm{c}$ & $20 \mathrm{e}$ & 0.3093 & $1083 \mathrm{abc}$ & 11,62 & $21,42 \mathrm{~b}$ \\
\hline D3S1 & $46.7 \mathrm{~d}$ & $22.32 \mathrm{f}$ & 0.3093 & $1000 \mathrm{a}$ & 11,61 & $8,31 \mathrm{a}$ \\
\hline D3S2 & $48.4 \mathrm{e}$ & $23.42 \mathrm{~g}$ & 0.3093 & $1050 \mathrm{ab}$ & 11,67 & $8,29 \mathrm{a}$ \\
\hline D3S3 & $48.4 \mathrm{e}$ & $24.02 \mathrm{~h}$ & 0.3083 & $1050 \mathrm{ab}$ & 11,62 & $8,36 \mathrm{a}$ \\
\hline DMRT5\% & $*$ & $*$ & tn & $*$ & tn & $*$ \\
\hline
\end{tabular}

Keterangan: Angka rata-rata yang diikuti oleh huruf yang sama pada satu kolom yang sama menunjukkan tidak berpengaruh nyata pada.DMRT 5\%.

tn : Tidak Berpengaruh Nyata

* : Berpengaruh Nyata

\section{Overrun}


Berdasarkan dari hasil uji lanjut subtitusi pemanis (D) serta interaksi perlakuan subtitusi pemanis dan jenis stabilizer (DxS) berpengaruh nyata pada variabel pengamatan overrun. Sedangkan perlakuan berbagai jenis stabilizer (S) tidak berpengaruh nyata. Pengaruh konsentrasi gula pada uji overrun dapat dilihat pada Tabel 2.

Menurut Badan Standarisasi Nasional (1995) es krim yang berkualitas baik memiliki overrun $70-100 \%$ untuk es krim normal, dan untuk industri rumah tangga overrun 35 - 50\% yang disebut dengan es krim lunak. Pada penelitian es krim ubi jalar ini diperoleh nilai overrun yaitu 38,2 - 48,4\% yang artinya memenuhi standar baik untuk skala rumah tangga. Penambahan sukrosa juga menyebabkan adonan es krim menjadi kental sehingga kemampuan membentuk rongga-rongga udara yang dapat memerangkap udara menjadi rendah. Hal ini sesuai dengan Farida (2005) yang menyatakan bahwa sukrosa memiliki pengaruh terhadap total padatan es krim dan mempengaruhi jumlah udara yang terperangkap pada adonan es krim sehingga menyebabkan overrun menurun. Hal ini juga sesuai dengan Syahbania (2012) yang menyatakan bahwa sukrosa juga dapat meningkatkan kekentalan dan total padatan es krim serta memperbaiki tekstur es krim, jika total padatan tidak lebih dari 42\% dan kadar sukrosa kurang dari 16\%. Hal serupa dikemukakan oleh Marshall dan Arbuckle (1996) bahwa adonan yang kental akan menyebabkan overrun rendah, karena adonan mengalami kesulitan untuk mengembang dan udara sulit menembus masuk permukaan adonan. Pada Interaksi Perlakuan Pemanis dan Stabilizer.

Nilai es krim ditentukan oleh bahan baku pada saat pembuatan. Lemak merupakan bahan baku es krim, yang mana fungsi lemak memberikan tekstur dari pengadukan. Metode pengadukan dan pendinginan secara serempak dalam pembuatan es krim ini ternyata menimbulkan masalah yaitu naiknya krim ke permukaan dan hal ini tidak diinginkan dalam pembutan es krim. Krim pada dasarnya terdiri atas globula kecil lemak yang tersuspensi dalam air. Globula -globula ini tidak tidak saling bergabung sebab masing - masing dikelilingi membrane protein yang menarik air, dan airnya membuat masingmasing globula tetap menjauh. Pengadukan akan merusak membrane protein yang membuat lemak tersebut dapat saling mendekat dan akibatnya krim akan naik kepermukaan. Masalah ini dapat diselesaikan dengan menambahkan emulsifier pada campuran es krim. Molekul emulsifier akan menggantikan membrane protein, satu ujung molekulnya akan melarut di air, sedangkan ujung satub nya akan melarut di lemak. Hal ini dipertegas oleh Pantzaris (1995) bahwa pemakaian emulsifier dimaksudkan untuk mengikat air agar berikatan dengan lemak sehingga membentuk es krim yang mempunyai daya mengembang yang bagus.

Overrun es krim yang dibuat dengan mesin ternyata berbeda nyata dan lebih tinggi dibanding dengan overrun es krim yang dibuat dengan metode konvensional. Hal ini karena dengan menggunakan mesin, proses homogenisasi/ pengadukan dan pendinginan berjalan serempak dan tidak terpisah, selain itu suhu dan tingkat getaran/pengadukan relatif lebih konstan sehinggga memungkinkan udara masuk kedalam adonan lebih banyak dan merata. Sedangkan metode konvensional yang dilakukan tidak memungkinkan pengadukan dan pendinginan dilakukan secara serentak, tetapi dilakukan secara bergantian yaitu pengadukan/homogenisasi, pendinginan, pengadukan kemudian pendinginan kembali. Proses yang demikian dan adanya perubahan suhu memungkinkan udara yang terperangkap ke dalam adonan sangat tergantung pada kecepatan dan lama pengadukan dan suhu.

\section{Uji Leleh}

Berdasarkan dari hasil uji lanjut subtitusi pemanis (D) serta interaksi perlakuan subtitusi pemanis dan jenis stabilizer $(\mathrm{DxS})$ berpengaruh nyata pada variabel pengamatan uji leleh. Sedangkan perlakuan berbagai jenis stabilizer (S) tidak berpengaruh nyata. Kecepatan meleleh merupakan waktu yang dibutuhkan es krim untuk meleleh sempurna. Lamanya waktu pelelehan merupakan waktu yang diperlukan es krim pada volume tertentu untuk mencair secara keseluruhan pada suhu ruang. Hal ini disebabkan karena penambahan bahan tambah pada es krim semakin banyak. Semakin rendah konsentrasi penambahan gula, maka semakin lama waktu yang dibutuhkan es krim tersebut untuk meleleh. Pengaruh konsentrasi gula pada uji leleh dapat dilihat pada Tabel 2.

Konsentrasi penstabil, pengemulsi, bahan-bahan serta kondisi pemrosesan dan kondisi penyimpanan juga mempengaruhi waktu leleh. Hal ini sesuai dengan pendapat Nurjannah (2003), penstabil yang digunakan dalam es krim berfungsi untuk memperbaiki stabilitas emulsi, meningkatkan kehalusan tekstur dan memperlambat melelehnya es krim saat disajikan. Resistensi es krim tersebut dapat dipengaruhi oleh beberapa faktor, yaitu nilai overrun, kadar lemak dan tekstur es krim. Waktu leleh berhubungan dengan total padatan dalam es krim. Semakin tinggi total padatan dapat mengurangi titik beku adonan, sehingga mengakibatkan jumlah air bebas yang terperangkap semakin banyak. Peningkatan jumlah air bebas yang terperangkap akan mengakibatkan waktu leleh semakin lambat (Gaman dan Sherrington, 1992). Pada uji proksimat daya leleh berpengaruh nyata pada interaksi perlakuan seperti pada Tabel 2.

Kecepatan meleleh es krim sangat dipengaruhi oleh bahan- bahan yang digunakan dalam pembuatan es krim, es krim yang baik adalah es krim yang tahan terhadap pelelehan pada saat dihidangkan pada suhu ruangPada penelitian kali ini, nilai uji leleh tertinggi yaitu pada perlakuan D3S3 (100\% stevia dan CMC) yaitu sebesar 24,02 menit. Dan yang terendah yaitu pada perlakuan D1S1 (100\% gula pasir dan agar) yaitu sebesar 14,06 menit. Perbedaan waktu leleh disebabkan oleh kadar gula yang ada pada bahan, bahan yang memiliki 
lebih banyak gula akan menyerap air sehingga air yang terkandung lebih sedikit dan es krim yang terbentuk memiliki kristal es yang kecil dan mudah meleleh. Sedangkan pada bahan yang tidak diberi gula atau diganti dengan stevia maka air yang ada pada bahan tidak terserap dan mengakibatkan terbentuknya kristal es yang besar dan sulit untuk meleleh.

\section{Uji Kadar Serat}

Serat merupakan istilah umum dari campuran heterogen komponen pangan yang tidak dicerna dalam usus halus termasuk zat dinding sel tanaman (selulosa, hemiselulosa, pektin dan lignin) serta polisakarida interseluler gum dan mucilage (Dewanti et al, 2013). Berdasarkan dari hasil uji lanjut subtitusi pemanis (D), perlakuan berbagai jenis stabilizer (S) dan interaksi perlakuan subtitusi pemanis dan jenis stabilizer (DxS) tidak berpengaruh nyata pada variabel pengamatan kadar serat Tabel 2.

Dari hasil analisis data diatas, tidak terdapat perbedaan nyata untuk kandunag serat pada es krim ubi jalar ungu. Hal ini dikarenakan serat pada es krim berasal dari ubi dan konsentrasi ubi yang digunakan sama untuk semua perlakuan. Selain itu serat dari daun stevia juga tidak memberikan perbedaan yang signifikan karena daun diekstrak dan hasil ekstraknya disaring terlebih dahulu. Kadandungan serat yang paling besar adalah perlakuan D3S3 (100\% stevia dan CMC) yaitu sebesar 0,3107\%. Dan yang terendah yaitu pada perlakuan D1S1 (100\% gula pasir dan agar) yaitu sebesar 0,3083\%. Data ini sesuai dengan bagan nilai gizi ubi jalar dimana setiap 100 grm ubi jalar mengandung 3\% serat Arixs (2006).

Serat berfungsi untuk mencegah berbagai penyakit peradaban yang banyak muncul seperti jantung koroner, diabetes mellitus dan konstipasi Kandungan serat pada es krim belum dapat memenuhi kebutuhan serat per hari, sehingga perlu mengkonsumsi makanan sumber serat lain. Kekhawatiran akan makanan berserat dapat dikurangi jika dipertahankan pola makan yang ada dengan mengkonsumsi makanan pokok (serealia), kacangkacangan, sayuran dan buah-buahan dalam jumlah yang cukup.

\section{Uji Viskositas}

Viskositas adalah parameter untuk mengukur kekentalan suatu cairan atau fluida. Pengukuran viskositas pada es krim penting dilakukan karena kekentalan dapat mempengaruhi mobilitas molekul air di dalam ruang antara partikel di es krim menjadi semakin sempit atau lebar (Widiantoko \& Yunianta, 2014).

Berdasarkan dari hasil uji lanjut subtitusi pemanis (D) serta interaksi perlakuan subtitusi pemanis dan jenis stabilizer $(\mathrm{DxS})$ berpengaruh nyata pada variabel pengamatan kadar abu. Sedangkan perlakuan berbagai jenis stabilizer (S) tidak berpengaruh nyata (Tabel 2.).

Nilai viskositas yang paling besar adalah perlakuan D1S1 (100\% gula pasir dan agar) yaitu sebesar 1400 cP. Dan yang terendah yaitu pada perlakuan D3S3 (100\% stevia dan CMC) yaitu sebesar $1050 \mathrm{cP}$. Pengaruh konsentrasi gula pada viskositas dapat dilihat pada Tabel 4.3.10 berikut.

Pada penelitian kali ini jenis bahan penstabil tidak memberikan pengaruh yang nyata. Hal ini dikarenakan semua bahan penstabil memang memiliki fungsi yang sama yaitu mengentalkan dan memperbaiki tekstur es krim. Viskositas dipengaruhi oleh bahan pada adonan. Salah satu bahan yang ada dalam es krim yang mempengaruhi kekentalan adalah gula. Gula yang ditambahkan pada es krim akan menambah tingkat kekentalan pada es krim karenanya nilai viskositasnya akan semakin tinggi. Viskositas dalam larutan dipengaruhi oleh berat molekul, konsentrasi, $\mathrm{pH}$ dan konsentrasi garam, semakin tinggi berat molekul dan konsentrasi maka viskositas semakin tinggi (Sukardi 2002). Pada uji proksimat kadar abu berpengaruh nyata pada interaksi perlakuan seperti pada Tabel 4.3 .11 berikut.

Menurut Belizt (1986), viskositas dipengaruhi oleh konsentrasi dan BM penstabil,semakin tinggi nilai BM dan konsentrasi penstabil maka viskositas produk akan semakin meningkat. Hal ini juga diperkuat oleh Akoh (1998) bahwa fat mimetics berbasis karbohidrat dapat meningkatkan viskositas suatu bahan.

\section{Uji Antioksidan}

Antioksidan adalah senyawa kimia yang dapat menyumbangkan satu atau lebih eklektron kepada radikal bebas, sehingga radikal bebas tersebut dapat diredam (Suhartono, 2002). Berdasarkan dari hasil uji lanjut subtitusi pemanis (D), perlakuan berbagai jenis stabilizer (S) dan interaksi perlakuan subtitusi pemanis dan jenis stabilizer (DxS) tidak berpengaruh nyata pada variabel pengamatan antioksidan (Tabel 2.).

Kadar antioksidan yang paling besar adalah perlakuan D3S2 (100\% stevia dan Gelatin) yaitu sebesar 11,67\%. Dan yang terendah yaitu pada perlakuan D1S1 (100\% gula pasir dan agar) yaitu sebesar 11,58\%. Kadar antioksidan pada penelitian kali ini tidak berbeda nyata dikarenakan komposisi bahan yang digunakan relatif sama. Selain itu stevia juga tidak memberikan pengaruh signifikan pada kadar antioksidan karena penggunaannya sangat sedikit.

Antosianin merupakan salah satu jenis antioksidan alami. Antioksidan alami yang terkandung pada ubi jalar ungu dapat menghentikan reaksi berantai pembentukan radikal bebas dalam tubuh yang diyakini sebagai penyebab penuaan dini dan beragam penyakit yang menyertai seperti penyakit kanker, jantung, tekanan darah tinggi, dan katarak (Sibuea, 2003).

\section{Uji Gula Total}

Kadar gula total merupakan kandungan gula keseluruhan dalam suatu bahan pangan yang terdiri dari gula pereduksi dan gula non-preduksi, jenis gula total yaitu golongan monosakarida, disakarida, oligosakarida 
dan polisakarida (Rohman dan Soemantri, 2007). Pengaruh konsentrasi gula pada kadar gula total dapat dilihat pada Tabel 2 .

Gula total pada es krim berasal dari ubi jalar ungu, susu sapi, gula dan stevia. Komposisi es krim yang berbeda membuat konsentrasi gula dalam es krim juga berbeda. Penggunaan gula pasir menghasilkan kadar gula semakin tinggi hal ini karena dalam gula pasir mengandung karbohidrat atau gula sebesar 94,0 g dalam 100 gram (Darwin, 2013). Menurut Cahyadi (2006), jumlah kalori dari sukrosa yaitu 3,94 kkal/gram. Semakin tinggi penambahan sukrosa maka jumlah kalori yang dihasilkan juga semakin tinggi. Sukrosa sering dijadikan sebagai tolak ukur bagi tingkat kemanisan gula. Sukrosa memiliki intensitas rasa manis sebesar $100 \%$.

Sedangkan peambahan pemanis stevia menurunkan kadar gula total pada es krim. Penggunaan stevia yang lebih sedikit daripada gula pasir. Menurut Buchori (2007), daun Stevia berisi glycoside yang mempunyai rasa manis tapi tidak menghasilkan kalori. Stevioside dan rebaudioside merupakan konstituen utama dari glycoside dengan gabungan dari molekul gula yang berbeda seperti yang terdapat pada tanaman stevia. Glycoside yang digunakan secara komersial dinamakan stevioside yang memberikan rasa manis 250 - 300 kali dari gula. Selain itu berdasarkan hasil penelitian, disimpulkan bahwa penggunaan bubuk daun stevia pada es krim berpengaruh dalam meningkatkan total padatan es krim, serta menurunkan kadar air, total gula dan total kalori es krim (Sriwahyuni, 2018). Pada uji proksimat kadar abu berpengaruh nyata pada interaksi perlakuan seperti pada Tabel 4.3 .13 berikut.

Berdasarkan dari hasil uji lanjut subtitusi pemanis (D) serta interaksi perlakuan subtitusi pemanis dan jenis stabilizer $(\mathrm{DxS})$ berpengaruh nyata pada variabel pengamatan gula total. Sedangkan perlakuan berbagai jenis stabilizer (S) tidak berpengaruh nyata. Nilai gula total yang paling besar adalah perlakuan D1S2 (100\% gula pasir dan gelatin) yaitu sebesar 35,21. Dan yang terendah yaitu pada perlakuan D3S2 (100\% stevia dan gelatin) yaitu sebesar 8,29.

\section{KESIMPULAN}

Berdasarkan hasil penelitian yang dilaksanakan dapat disimpulan sebagai berikut: Perlakuan jenis stabilizer (S) tidak berpengaruh nyata terhadap semua variabel pada analisis proksimat, antioksidan dan sensoris es krim. Perlakuan perbandingan konsentrasi pemanis (D) berpengaruh nyata terhadap semua variabel kecuali pada variabel aroma. Interaksi perlakuan (DxS) berpengaruh nyata terhadap analisis proksimat pada semua variabel, kecuali pada variabel, kadar serat kasar antioksidan, dan aroma. Perlakuan terbaik pada analisis proksimat analisis sensorik adalah perlakuan menggunakan $50 \%$ gula pasir dan $50 \%$ stevia dan penstabil agaragar (D2S1) dengan skor organoleptik aroma, tekstur, rasa dan kesukaan masing-masing adalah 3,80 (normal); 3,60 (agak lunak); 3,80 (baik); 4,10 (suka), dan nilai fisikokimia overrun, waktu leleh, kadar serat, viskositas, antioksidan, dan kadar gula berturut-turut adalah 42,5\%; 14,06 menit; 0,3107\%; 1.217 cP; 11,65\%; $20,33 \%$. Berdasarkan hasil penelitian yang diperoleh, perlu adanya penelitian lebih lanjut mengenai uji daya simpan, cemaran, dan indeks glikemik untuk produk es krim, agar nantinya es krim ubi jalar ungu dengan pendmbahan pemanis stevia dapat menjadi pangan fungsional yang diterima masyarakat.

\section{UCAPAN TERIMA KASIH}

Terima kasih disampaikan kepada Lembaga Penelitian dan Pengabdian Masyarakat Universitas Muhammadiyah Purwokerto yang telah membiayai penelitian ini.

\section{DAFTAR PUSTAKA}

Susilorini, Tri Eko dan Manik Eirry Sawitri. 2006. Produk Olahan Susu. Depok: Penebar Swadaya. Hal: 83.

Harris, Asriyadi. 2011. Pengaruh Subtitusi Ubi Jalar (Ipomea batatas) dengan Susu Skim Terhadap Pembuatan Es Krim. Makasar. Universitas Hasanuddin.

Pratama, Wibi P dan Simamora Novita S, 2018. PRODUK KONSUMSI : Saat Pasar Es Krim Semakin Panas.

Suda, I., T. Oki, dan M. Masuda. 2003. Physiological Functionality of Purple-Fleshed Sweet Potatoes Containing Anthocyanins and Their Utilization in Foods. Japan Agricultural Research Quarterly (JARQ). JIRCAS. Japan. P. 1-10.

Meyer, L.H. 1982. Food Chemistry. The AVI Publishing Company Inc. Westport. University of California.

Ginting Erliana, Joko S. Utomo, Rahmi Yulifianti, dan M. Jusuf1. 2011. Potensi Ubijalar Ungu sebagai PanganFungsional. Iptek Tanaman Pangan Vol. 6 No. 1 - 2011.

Raini, Mariana dan Ani Isnawati. 2011. Kajian: Khasiat dan Keamanan Stevia sebagai Pemanis Pengganti Gula. Jurnal Media Litbang Kesehatan Volume 21 Nomor 4 Tahun 2011. 
Savita, S.M., K. Sheela, Sharan Sunanda, A.G. Shankar dan Parama Ramakrishna, 2004, Stevia rebaudian-A functional component for food industry, J. Hum. Ecol., 15(4): 261-264.

Widodo, Naimatun Munawaroh, Indratiningsih. 2015. Produksi Low Calorie Sweet Bio-Yoghurt Dengan Penambahan Ekstrak Daun Stevia (Stevia Rebaudiana) Sebagai Pengganti Gula. Agritech, Vol. 35, No. 4, November 2015.

Buchori, L. 2007. Pembuatan Gula Non Karsinogenik Dari Daun Stevia. Jurnal Reaktor Vol. II No.2. Jurusan Teknik Kimia, Fakultas Teknik, Universitas Dipenogoro, Semarang.

Buckle, K.A.,1987. Ilmu Pangan. Universitas Indonesia Press.Jakarta

Istiqomah, K., Wiwik, S. W., dan Yhulia, P. 2017. Karakterisasi Es Krim Edamame Dengan Variasi Jenis dan Jumlah Penstabil. Jurnal Agroteknologi. 11(2):139 - 147.

Hilmy, Halim, Bambang Nugroho dan Arif Prashadi Santosa. 2019. Karakteristik Proksimat, Antioksidan dan Sensoris Mochi Substitusi Ketan Hitam (Oryza sativa Linn. var glutinosa) dengan Penambahan Pemanis Dari Ekstrak Daun Stevia (Stevia rebaudiana Bertoni M.). Universitas Muhammadiyah Purwokerto. (Skripsi).

[BSN] Badan Standarisasi Nasional. 2006. Petunjuk Pengujian Organoleptik dan atau Sensori. SNI 01-23462006.

Hadiwiyoto, S. 1983. Teori dan Prosedur Pengujian Mutu Susu dan Hasil Olahannya. Yogyakarta: Liberty.

Nugroho, Y.A dan Joni Kusnadi. (2015). Aplikasi Kulit Manggis (Garcinia Mangostana L.) sebagai Sumber Antioksidan pada Es Krim. Jurnal Pangan dan Agroindustri Vol. 3 No.4 p.1263-1271, September 2015.

AOAC. (1995). Official Methods of Analysis of Association of Official Analytical Chemist. AOAC International. Virginia USA.

H. D. Goff, v. J. Davidson, and E. Cappi. 1994. Viscosity of Ice Cream Mix at Pasteurization Temperatures. Department of Food Science University of Guelph Guelph, ON, Canada. J Dairy Sci 77:2207-2213

Shekhar ,Tailor Chandra and Anju, Goyal. 2014. Antioxidant Activity by DPPH Radical Scavenging Method of Ageratum conyzoides Linn. Leaves . American Journal of Ethnomedicine, 2014, Vol. 1, No. 4, 244-249. ISSN: 2348-9502.

Sudarmadji, S; B. Haryono dan Suhardi. (1989). Analisa Bahan Makanan dan Pertanian. Penerbit Liberty. Yogyakarta.

Prasetyo, D. 2013. "Pengaruh Penambahan dan Lama Blanching Sari Kedelai (Glycine max) terhadap Sifat Fisik, Kimia, serta Organoleptik Es Krim Ubi Jalar Kuning (Ipomea batatas L)”. Skripsi. Universitas Brawijaya, Malang.

Muse,M.R, \& R.W. Hartel. (2004). Ice Cream Stuctural Element that Affect Melting Rate and Hardness. J.Dairy Sci. 87:1-10.

Arbuckle, W.S. (1986). Ice Cream. The AVI Publishing Company, Inc. New York.

Rahmawati, W. 2012. Karakteristik pati talas (Colocasia esculenta (L) Schoott) sebagai alternatif sumber pati industry di Indonesia. Jurnal Teknologi Kimia dan Industri, Vol. No. 1:347-351.

[BSN] Badan Standarisasi Nasional. 2006. Syarat Mutu Es Krim. SNI 01-3713-1995.

Farida, Z. 2005. Kekerasan dan overrun es krim yang dibuat menggunakan susu sapi maupun susu kambing dengan persentase gula yang berbeda. Skripsi. Universitas Jenderal Soedirman Fakultas Peternakan. Purwokerto. Hal 20 - 24.

Syahbania, N. 2012. Studi pemanfaatan talas (Colocasia esculenta) sebagai bahan pengisi dalam pembuatan es krim. Program Studi Ilmu dan Teknologi Pangan Jurusan Teknologi Pertanian. Fakultas Pertanian. Universitas Hasanuddin. Makassar.

Marshall, R.T., and Arbuckle, W.S. 1996. Ice Cream. 5th ed. Internasional Thomson Publ., New York.

Pantzaris. 1995. Principle of Barley Chemistry. Wiley Eastern Private Ltd. New Delhi.

[Nurjanah, Enung. 2003. Pengaruh Jenis dan Konsentrasi Bahan Penstabil terhadap Mutu Velva Wortel (Daucus carota L.). Skripsi Jurusan Gizi Masyarakat dan Sumberdaya Keluarga, Fakultas Pertanian, Institut Pertanian Bogor. 
Respati, N. 1999. Subsitusi Lemak Susu dengan Minyak Kelapa Sawit Merah padaEs Krim. Skripsi Fakultas Teknologi Pertanian, Universitas Gadjah Mada, Yogyakarta.

Gaman PM, Sherrington KB. 1992. Ilmu Pangan Pengantar Ilmu Pangan, Nutrisi dan Mikrobiologi Ed. 2nd . Yogyakarta: Gadjah Mada University Press.

Dewanti, R., M. Irham dan Sudiyono. 2013. Pengaruh penggunaan enceng gondok (Eichornia crassipes) terfermentasi dalam ransum terhadap persentase karkas, non-karkas, dan lemak abdominal itik lokal jantan Umur Delapan Minggu. Buletin Peternakan Vol. 37(1): 19-25, Februari 2013. hlm. 19-25.

Arixs.(2006). Mengenal Olahan Bahan Pangan Nonberas. Bandung :Cybertokoh.

Widiantoko, Rizky Kurnia dan Yunianta. 2014. "Pembuatan Es Krim Tempe - Jahe (Kajian Proporsi Bahan dan Penstabil Terhadap Sifat Fisik, Kimia dan Organoleptik”. Jurnal Pangan dan Agroindustri 2(1): 54-66.

Sukardi. Diklat Teknologi Polisakarida dan Gula. Malang: Jurusan THP Fakultas Pertanian UMM. 2002.

Belitz, H.D. dan Grosch, W. (1987). Food Chemistry. 2nd Ed. Springer.Page 232.

Suhartono, E., Fujiati, Aflanie, I. 2002. Oxygen Toxicity by Radiation and Effect of Glutamic Piruvat Transamine (GPT) Activity Rat Plasma after Vitamine C Treatmen. Diajukan pada Internatinal seminar on Environmental Chemistry and Toxicology. Yogyakarta.

Sibuea, P, 2003, Antioksidan Senyawa Ajaib Penangkal Penuaan Dini, Sinar Harapan, Yogyakarta.

Sriwahyuni, 2018.Penggunaan Bubuk Daun Stevia (Stevia rebaudiana) pada Es Krim Ditinjau dari Total Padatan, Kadar Air, Total Gula dan Total Kalori. Sarjana thesis. Universitas Brawijaya. 